\title{
A ANGÚSTIA DE ADÃO NA AMÉRICA
}

\author{
MARIA BERnARDETE RAMOS Flores \\ Universidade Federal de Santa Catarina \\ Florianópolis | Santa Catarina | Brasil \\ mbernaramos@gmail.com \\ orcid.org/0000-0002-9438-031X
}

A viagem metafísica de Adán Buenosayres, protagonista da novela de mesmo nome, escrita pelo poeta argentino Leopoldo Marechal, provocou o encontro com Xul Solar e Ismael Nery, o primeiro, argentino e o segundo, brasileiro. A tônica do encontro fundou-se na arte marcada pela estética da angústia, de raiz cristã-adâmica-kierkegaardiana, própria da linguagem dos poetas e pintores que comunicaram o desassossego no mundo contingente, e desejaram transcender o tempo e o espaço, à busca do Paraíso perdido ou da infância da humanidade. A arte metafísica foi a linguagem estética que ajudou o artista agônico a reconectarse com o infinito e a encontrar a essência da humanidade. $\mathrm{O}$ afeto agônico que irrigou a arte de Leopoldo, Xul e Ismael, alçados aqui a signos da angústia na América, é parte da ansiedade cultural que se dá no plano psíquico no quadro da civilização ocidental. Portanto, a arte metafísica de traço agônico, praticada na América, vem da mesma fonte, a fonte bíblica, que irrigou a angústia na metrópole, a Europa.

angústia - arte metafísica - Kierkegaard 


\title{
THE ANGUISH OF ADAM IN AMERICA
}

\author{
MARIA BERNARDETE RAMOS FLORES \\ Universidade Federal de Santa Catarina \\ Florianópolis | Santa Catarina | Brazil \\ mbernaramos@gmail.com \\ orcid.org/0000-0002-9438-031X
}

The metaphysical journey of Adán Buenosayres, protagonist of the novel of the same name, written by the Argentine poet Leopoldo Marechal, caused the encounter with Xul Solar and Ismael Nery, the first, Argentine and the second, Brazilian. The focus of the meeting was based on art marked by the aesthetics of anguish, of Christian-AdamicKierkegaardian roots, typical of the language of the poets and painters who communicated restlessness in the contingent world, and wished to transcend time and space, in search of the lost Paradise or the childhood of humanity. Metaphysical art was the aesthetic language that helped the agonic artist to reconnect with the infinite and to find the essence of humanity. The agonic affection that irrigated the art of Leopoldo, Xul and Ismael, raised here to signs of anguish in America, is part of the cultural anxiety that occurs on the psychic plane within the framework of Western civilization. Therefore, the agonistic metaphysical art, practiced in America, comes from the same source, the biblical source, which irrigated the anguish in the metropolis, Europe. 
Por que a história de Adão e Eva - que ocupa cerca de uma página e meia das 1078 que compõem uma edição moderna da Bíblia, sobre minha mesa - se impõe com tanta eficiência e com tanta facilidade? (...) ... esses poucos versículos num livro antigo têm servido de espelho no qual parecemos vislumbrar a longa história de nossos medos e desejos.

(Greenblatt 2018, 13).

É profunda a raiz desse desassossego ... não há dúvida de que o ápice do itinerário do protagonista é o da noite em frente à igreja de San Bernardo, e a crise de Adán sozinho em sua angústia, sua sede de unidade. (...) ... Adán toca o fundo da angústia ocidental contemporânea. ... sua horrível náusea diante do Cristo da Mão Quebrada toca e se reconcilia com a náusea de Roquentin no jardim botânico e a de Mathieu nos cais do Sena. (Cortázar 1949, 232) ${ }^{1}$.

Quando comecei a pesquisa sobre Xul Solar, em 2009, por ocasião de um estágio pós-doutoral em Buenos Aires, na Universidad de San Martin, as fontes me diziam que a novela Adan Buenosayres de Leopoldo Marechal, publicado em 1948, era um "retrato" do artista argentino. Pus-me a ler o grosso volume de 740 páginas, que encontrei numa loja de livros usados, uma edição espanhola, em Barcelona, de 1981, e já nas primeira páginas suspeitei que havia ali fios que me conectavam a Ismael Nery, pintor brasileiro que era tema de minha pesquisa no Brasil. E, se à princípio não identifiquei exatamente um "retrato" de Xul Solar, na paródia que Marechal faz do artista na figura do personagem "o astrólogo Schultze", percebi que havia alguma identidade artística entre Ismael, Xul e Leopoldo, três artistas das vanguardas latinoamericanas.

Ismael Nery (1900-1934), produziu poesia, desenho e pintura, além de um sistema filosófico denominado Essencialismo. Dividido entre erotismo e sensibilidade extremada, era um homem de peculiar inquietação existencial. Místico, compartilhou com a mãe, a angústia pelo pecado não praticado ou pela dor não resolvida. Considerado o "pintor maldito" (Bento 1973, 9) do modernismo brasileiro, não atendeu ao ideário imagético do Brasil nacionalista. $\mathrm{Na}$ pintura de autorretratos, do casal (em geral, ele e a esposa) e da triangulação de figuras, de traços andróginos, Ismael procurava a essência humana, a abstração do tempo e do espaço, os mistérios da relação entre finitude e infinitude da vida, a unidade sexual perdida com a queda do Paraíso adâmico.

Xul Solar (1887-1963), também foi um artista místico, hoje é reconhecido como um dos grandes representantes da vanguarda argentina, embora em vida tenha sido pouco compreendido. "El joven Alejandro Schulz Solari se habia propuesto inventar un mundo para él y sus hermanos..." (Gradowczyk 1994, 11). Como pintor, dedicou-se às formas expressivas, em aquarela ou na têmpera, que comunicassem mensagens espirituais, fazendo o uso recorrente de símbolos do seu repertório peculiar referentes a um mundo atemporal, universal e visionário. Além de pintor, foi músico, astrólogo, filólogo (criou dois idiomas: panlengua - idioma internacional; neocriollo, idioma latinoamericano baseado em sílabas e termos de raízes do Espanhol e do Português). Iniciado pelo mago inglês Aleister Crowley, registrou 64 visões exotéricas. Xul concebeu uma interpretação astrológica universal, por

${ }^{1}$ De muy honda raíz es ese desasosiego; más hondo en verdad que el aparato alegórico con que lo manifiesta Marechal; no hay duda que el ápice del itinerario del protagonista lo de la noche frente a la iglesia de San Bernardo, y la crisis de Adán solitario en su angustia, su sed unitiva. Es por abi (no en las vías metódicas, no en la simbología superficial y gastada) por donde Adán toca el fondo de la angustia occidental contemporánea. Mal que le pese, su horrible náusea ante el Cristo de la Mano Rota se toca y concilia con la náusea de Roquentin en el jardín botánico y la de Matbieu en los muelles del Sena (Cortázar 1949, 232). 
intermédio da qual estabelecia correspondências entre o cosmo e o humano, capaz de reconciliar o infinito e o finito, o universo e a vida humana, enfim, o macro e o microcosmo. Xul estava sempre em busca da unidade original regida pela eternidade do mundo espiritual ${ }^{2}$.

Leopoldo Marechal (1900-1970) é considerado um dos grandes nomes das letras argentinas, primeiro como poeta, mas também escreveu novelas e deixou peças de teatro inéditas. Na juventude, participou da vanguarda argentina, junto com Xul Solar, em torno da Revista Martin Fierro (1924-1927), de tônica vitalista e criollista. Depois de 1930, encaminhou-se por uma paulatina conversão de índole espiritual e religiosa, católica, tornando-se militante e teórico do peronismo. A novela, que tem por título Adán Buenosayres, trata de uma narrativa metafórica, na qual o protagonista de nome Adán, antonomásia de Leopoldo Marechal, "renega", de forma irônica, seus antigos companheiros da vanguarda argentina dos anos de 1920: Jorge Luís Borges, Jacobo Fijman, Raul Scalabrini Ortíz, Norah Lange, Xul Solar.

Adán Buenosayres está dividida em 7 partes. Nas cinco primeiras, o autor narra as aventuras filosóficas do seu herói Adán Buenosayres, desde o despertar metafísico naquela "mañana de octubre de 192.", até a meia noite do dia seguinte, em frente "a la iglesia de San Bernardo, ante la figura inmóvil del Cristo de la Mano Rota" (Marechal 1981, 10). A sexta parte da novela é uma espécie de autobiografia do protagonista da história, narrada na primeira pessoa. O melancólico Adán Buenosayres reflete sobre o terror do tempo e do espaço, sobre a origem divina do homem e sua queda, sobre a tensão entre finito e infinito e a busca da transcendência, permanência e essência das coisas. A fragilidade do corpo material seria compensada pela crença na existência de uma alma, essência, permanência e transcendência do espírito.

$\mathrm{Na}$ última parte do livro, uma descida ao inferno, à la Oscura Ciudad de Cacodelphia, é uma paródia de $A$ Divina Comédia de Dante Alighieri e, também, da Argentina contemporânea. "Marechal realiza (...) una compleja operación por la cual une su ideario católico con la idea de 'comunidad organizada' que acaba de fundar Juan Domingo Perón...” (Rocco-Cuzzi 2004, 465). A estrutura de seu inferno dantesco, compõe-se de diferentes círculos e hierarquias verticais. As figuras que ocupam esse espaço constituem-se de corpos híbridos, gelatinosos, gigantescos, corpos que flutuam sobre superfícies pútridas, glutões que vomitam, e toda uma galeria de sujeitos corruptos, aproveitadores, devassos, irresponsáveis, figuras nas quais se reconhecem, metaforizadas, políticos, poetas ou intelectuais das décadas de 1920 e 30, na Argentina.

Qual seria o "retrato" de Xul Solar na novela de Leopoldo Marechal, que eu deveria encontrar na leitura do livro? Em meio a tiradas irônicas, num "humorismo angélico", segundo diz Marechal no prólogo do livro, Xul Solar é caracterizado na figura do astrólogo Schultrze, inventor do inferno e guia dos labirínticos espaços subterrâneos de la ciudad oscura de Cacodelphia e, também, aquele que conhece e realiza diversas práticas rituais, diante dos olhares horrorizados de Adán. O astrólogo Schultre é um tipo raro, com seus conhecimentos sobre estrelas e planetas, dado a invenções, as mais estapafúrdias. $\mathrm{O}$ astrólogo invocara primeiro com o idioma argentino, depois com a etnografia

2 Apresentei os resultados da pesquisa sobre Xul Solar e Ismael Nery em artigos publicados em diversas revistas, coletâneas e congressos. Ao final de 10 anos de produção, esse material foi organizado em livro (Flores 2017). Sobre a angústia de Adão na América, tentando estabelecer vinculações metafísicas entre a arte de Ismael, Xul e Leopoldo Marechal, apresentei suas linhas iniciais no II Colóquio de História e Arte, em Florianópolis, em 2010. Desde então, o trabalho permaneceu como uma ideia que agora tive a oportunidade de desenvolver. 
nacional e também com a música. Pleno de ironia, o narrador informa que Schultze achava medíocre a música feita com sete notas e queria inventar música com 28 notas; tinha tentado inventar em Roma um piano-saxofón-bateria. E andava inventando um novo homem, o Neocriollo (Marechal 1981, 135).

Graciela Maturo (1999), especialista na obra de Marechal, considera que Adán Buenosayres, no gênero da viagem, é mais que uma experiência narrada. Trata-se de uma reflexão filosófica através da consciência meditativa de Adán, que usa a voz do próprio autor, em diálogo com as outras personagens, excompanheiros da geração martinfierrista, que deambulam num périplo pelas ruas e arrabaldes de Buenos Aires, no curso de dois dias. Uma viagem, que a crítica lhe tem atribuído vínculos com o Ulisses de Joyce. Porém, segundo Renata Rocco-Cuzzi (2004, 462), Leopoldo Marechal contesta essa afiliação: “cierto es que Joyce, en el Ulisses, toma de Homero la 'técnica del viaje', pero no toma como yo el simbolismo espiritual del viaje". Para Marechal, o protagonista do Ulisses de Joyce padece de dispersão, atomização e pulverização da unidade humana; está apartado da "realização espiritual" que ele, Marechal reclama para seu herói. Ao Ulisses de Joyce, Marechal considera que há "falta de qualquer pretensão metafísica".

Essa "pretensão metafísica", que já aparece no Prólogo indispensável do livro, no qual Marechal apresenta "Adán Buenosayres desde seu despertar metafísico...", foi a pedra de toque inicial para minha primeira intuição de que estava diante de um linguagem estética comum à cosmovisão dos artistas argentinos - Leopoldo Marechal e Xul Solar - e do artista brasileiro Ismael Nery. $O$ fio que enlaça o pensamento dos três tem base na estética metafísica, uma crença de que a existência do indivíduo transcende a realidade contingente, no tempo e no espaço. Por exemplo, no Autorretrato de IN, de 1927, que Ismael Nery pintou no ano em que estivera em Paris, vemos ao centro a figura do artista sentado numa cadeira que divide o quadro em dois espaços, à direita, uma paisagem parisiense com a Torre Eiffel e, à esquerda, o Pão-de-Açúcar representa a paisagem carioca. Sobrepostas à Torre Eiffel e ao Pão de Açúcar, perfis de Ismael refletidos no mesmo nível do seu rosto, no centro do quadro. Uma concomitância temporal e espacial para expressar sua ideia de tempo e espaço. Escrito no verso, aparece a seguinte frase: "Um homem que se estudar em um momento, não se conhecerá... O presente de um homem é o resultado do seu passado e do de seus antepassados...” (Nery, apud. Fernandez 1984, 150).

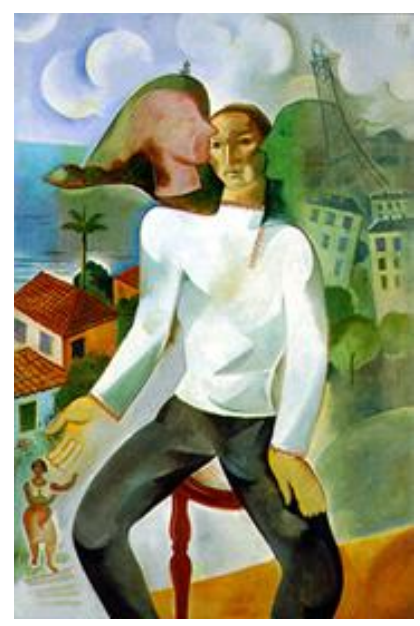

Figura 1: Ismael Nery. Autorretrato. 1927. Óleo sobre tela, 129/83 cm Col. Domingo Globbi, S Fonte: Catálogo, 1984, 172 


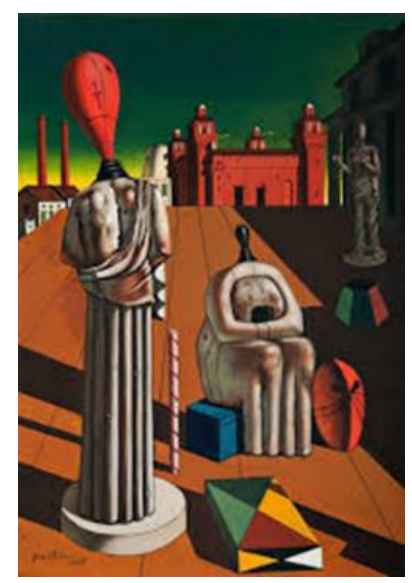

Figura 2: Giorgio de Chirico. As Musas Inquietantes. 1916-1918. Óleo sobre tela. 97 x 66 cm Coleção Particular. Fonte: Disponível em:

https://www.wikiart.org/pt/giorgio-de-chirico/the-disquieting-muses-1918-1 Acesso em: 08 ago. 2020

A arte metafísica, como um movimento de vanguarda, remete-se ao trabalho desenvolvido, principalmente, entre os anos de 1911 e 1920, por Giorgio de Chirico e Carlo Carrà, artistas italianos, e refere-se a uma arte moderna eivada de motivos da antiguidade clássica, criando ambientes misteriosos por aproximar, em perspectivas impossíveis, objetos que em si pertencem a tempos e espaços diferentes (Flores 2008).

No caso de Ismael Nery, Xul Solar e Leopoldo Marechal, a conotação metafísica aparece na linguagem estética que comunica a vontade de transcender a realidade local, para encontrar mundos arcaicos e míticos. Nesse diapasão, as soluções plásticas ou literárias primam pela abstração do tempo e do espaço, pelo desejo de transcender a realidade, pela angústia diante da finitude e pela tentativa de reconectar-se com o infinito, remetendo a mundos espirituais e a formas universais. Numa atitude, entre rejeição e aceitação da modernidade, compartem a visão cósmica de um mundo ideal com valorização de mitos e linguagens simbólicas. Lembrando aqui Charles Baudelaire e Walter Benjamin, a modernidade trouxera consigo a implacabilidade do tempo, que traz nos rastros da cultura a ideia de finitude, de transitório e fugidio, de tal modo que a identidade do poeta se instala paradoxalmente na instabilidade de um tempo continuum que avança em flecha, em meio ao efêmero e a banalidade do cotidiano.

$\mathrm{Na}$ dialética ou na tensão entre o desconforto ou o sentimento de malestar frente à realidade e o desejo ou a fantasia que impulsiona uma ação ou um movimento corporal para encontrar a saída da crise existencial, produz-se o sentimento de angústia. E, no desvão do afeto da angústia, acontece o ato criativo do artista agônico. Não que seja uma regra, mas o afeto agônico, por si só, aparece em obras de compositores, poetas e pintores, cujo sofrimento e tristeza fertilizam a arte, na esperança de encontrar a saída para seu mundo que se tornou insuportável ou que não apresenta as condições para realização da potencialidade do ser. Nesse sentido, a angústia pode ser libertadora. Não é outro o sentido do título Angústia e esperança que Oswaldo Giacoia Júnior (2018) dá para abordar o pensamento de Soren Kierkegaard.

A angústia, conforme o conceito "inventado" no século XIX por Kierkegaard e por Sigmund Freud, no século XX, refere-se a um afeto que não tem um objeto real para seus temores. Trata-se de uma sensação, de uma suspeita de que algo estranho se avizinha. Kierkegaard (1968) partira, em 1844, ano da 
publicação de $O$ conceito da angústia, do abismo irreconciliável que media o finito e o infinito, abismo sentido pela existência humana como uma angústia radical, um desamparo, onde a subjetividade limitada do "homem" se acha suspensa no nada de sua angústia. A angústia seria, então, um modo de fundir-se em um nada, mas é ao mesmo tempo a maneira de salvar-se do nada, que ameaça aniquilar o homem angustiado. Nessa dualidade, está enraizada a consciência do ato criativo como produto de um estado de crise. Diferente dos sentimentos de revolta, ressentimento, melancolia, pessimismo, que marcaram o pensamento moderno, o pathos agônico presente no processo criativo transforma o sentimento de catástrofe iminente na possibilidade ou na esperança de uma saída, de um milagre, amparada na crença da dimensão espiritual e imaginária que a obra de arte pode carrear.

Artistas agônicos

É um Hades fluido, quase vapor, sem céu, sem solo, rufo, cor em olhos fechado sob o sol, agitado por uma tempestade interior, em vértices e ondas e fervura. Em seus nódulos e espumas, diferentes multidões de homens flutuam passivamente e brilham de maneiras diferentes; também existem seres maiores e solitários na forma de peixes. (...), Mas o chamado desta Terra de baixo oprime o peito do corpo físico, e eu volto para mim mesmo, muito afligido por um longo tempo. (Xul Solar, s.d.). ${ }^{3}$

Acabaram-se os tempos.

Morreram as árvores e os homens,

Destruíram-se as casas,

Submergiram-se as montanhas.

Depois o mar desapareceu.

O mundo transformou-se numa enorme planície

Onde só existe areia e uma tristeza infinita.

Um anjo sobrevoa os destroços da terra,

Olhando a cólera de um Deus ofendido.

(Ismael Nery 1933).

Eles não sabem que, construindo seu poema com imagens que não guardam nenhuma ilusão entre si, você o faz para vencer o Tempo, manifestado na triste sucessão de coisas, e para que as coisas vivam um presente alegre em sua música; eles não sabem que, ao reunir em uma imagem duas formas muito distantes uma da outra, você o faz para derrotar o Espaço e a distância, para que o distante se encontre na alegre unidade do seu poema. (Leopoldo Marechal 1948). ${ }^{4}$

No Catálogo Xul invita a Klee, Jorge Glusberg sugere que o artista argentino, "Oitenta anos depois de Kierkegaard", "inaugura na América a estética da angústia." Nas suas pinturas, vemos "uma interpretação astrológica universal, por intermédio da qual [o artista] estabeleceu uma correspondência (...) entre o cosmo e o homem, capaz de reconciliar o infinito e o finito", tal como o problema levantado por Kiekegaard (Glusberg 1998, 34).

\footnotetext{
${ }^{3}$ Es un Hades fluido, quase vapor, sem céu, sem solo, rufo, cor em olhos cerrados debajo del sol, agitado por una tempestad interior, en vértices y ondas y hervor. En sus grumos y espumas distintas multitudes de hombres flotan pasivamente y destellan de distintas maneras, hay también seres solos, más grandes, en forma de peces. (...) Pero ya la llamada de esta Tierra desde abajo me oprime el pecho del cuerpo físico, y vuelvo a mí, muy afligido por mucho tiempo. Esse é um trecho de uma das 64 visões que Xul Solar deixou escritas em neocriolo, o idioma de sua invenção, hoje traduzidas para o espanhol. Ver: (Nelson,” 2005).

4 ... ellos no saben que, al edificar tu poema con imágenes que no guardan entre sí ninguna ilación, lo haces para vencer al Tiempo, manifestado en la triste sucesión de las cosas, y a fin de que las cosas vivan en tu canto un gozoso presente; ignoran ellos que, al reunir en una imagen dos formas demasiado lejanas entre sí, lo haces para derrotar al Espacio y la lejanía, de modo tal que lo distante se reúna en la unidad gozosa de tu poema. (Leopoldo Marechal 2013, 204). A data de 1948, que consta acima, na epígrafe, refere-se ao ano da publicação de Marechal.
} 
Antes de partir para a Europa, em 1912, Xul sentia-se isolado e incompreendido em Buenos Aires, que lhe parecia miserável. Sua angústia chegava à beira da desesperação. Cintia Cristiá $(2007,13)$ mostra uma passagem na qual Xul Solar cita uma frase do poema Les Fleurs do Mal, de Baudelaire, importante para caracterizar o estado de angústia da etapa inicial do jovem Alejandro. No poema Noche, Ouctubre, 1910, percebemos que Xul sente-se "asfixiado em meio à agitação de desejos"; parece-lhe que "névoas inimigas mortíferas se rivalizam"; seu espírito "agita-se e se revolta pelo espaço", procurando ajuda para fugir. "Nesta luta angustiosa me farei veterano; com minhas mãos, meus olhos e ouvidos ávidos, com meu ardente cérebro encontrarei o caminho (...) se não há país sem angústia para mim, todo eu, dentro de meus pensamentos, me farei um mundo!” (Catálogo 1990, 10).

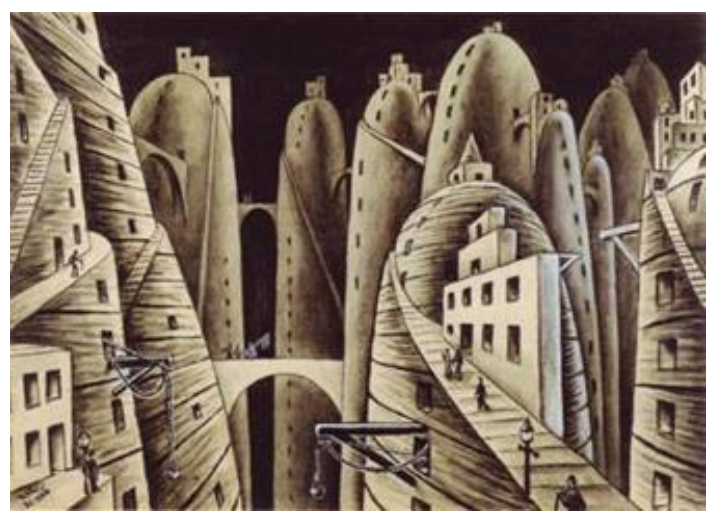

Figura 3: Xul Solar. Ciudad y abismo, 1946, témpera sobre papel, 35 x $50 \mathrm{~cm}$ Fonte: (Gradowczyk 1994, 173)

No contexto da Segunda Guerra, Xul Solar pinta paisagens estremecedoras. Em palheta monocromática, montes, vales, escadas, labirintos, passagens estreitas, torres, correias, pontes, muros, ausência de céu e de horizonte, parecem sugerir o drama da ascensão e da queda do homem, da luta entre as forças de luz e sombra, entre violência e paz, entre amor e ódio, entre vida e morte. Pálidas figuras humanas solitárias percorrem ou habitam essas paisagens. Em Fiordo (1943), em V alle hondo e Bordes de San Montes (1944), as escadas aparecem em ladeiras de imponentes montanhas, onde uma só figura humana enfrenta a imensidão. Em Muros e escaleras (1944) e Ciudá y abismos (1946), a paisagem natural transforma-se em paisagem urbana, sem perder sua magnitude esotérica e suas conotações simbólicas relativas à ascensão e queda. Uma sensação de labirinto se observa em Cavernas y troncos (1944). Como nas demais obras, a presença insólita da vida, onde o homem é apenas uma vivência minúscula, indecisa, agônica diante das encruzilhadas e buracos obscuros. Entre a série monocromática, há uma obra de 1946, Cavernas tronki, que o crítico Svanascini vê nela "premeditada profundidade de um canal subterrâneo construído com troncos, no qual deambulam cinco personagens aparentemente desvinculadas, enquanto três pêndulos assinalam um tempo irremediável. (Albós 2004, 239). 
Sobre o artista brasileiro Ismael Nery, seu primeiro biógrafo, Antônio Bento $(1973,32)$, também diz que sua arte é vizinha da filosofia de Kierkegaard. No Poema (1933), Ismael escreve: “A minha angústia aumentará em meus filhos. - Angústia que herdei de meus pais e de meus avós" 5 . A base da sua filosofia era o que Murilo Mendes denominara Essencialismo, a compreensão da essência das coisas, mediante a abstração do tempo e do espaço, propondo a felicidade de uma sabedoria harmônica, feita de equilíbrio entre o espírito e a matéria, entre a vida interior e a exterior, como via de acesso à transcendência. (Arriguci Jr. 2000, 109).

Ismael Nery tinha obsessão pela pintura de autorretratos, nos quais ele aparece como uma personagem andrógena, desdobrada em duas ou três faces. Esse traço de sua pintura não era só a procura por um estilo artístico. Tratavase de experimentação plástica à busca da essência da sua humanidade. No poema $E U$ (1933) ele escreve: "Eu sou a tangência de duas formas opostas e justapostas (...) Eu sou a unidade infinita / Eu sou um deus com princípio (...) Eu sou o sucessor do poeta Jesus Cristo / Encarregado dos sentidos do universo.” E ao final, o poema vai confrontar as forças que tendem para a anulação do indivíduo. "Eu sou o profeta anônimo / Eu sou os olhos dos cegos / Eu sou o ouvido dos surdos / Eu sou a língua dos mudos / Eu sou o profeta desconhecido, cego, surdo e mudo / Quase como todo mundo." Segundo a análise de Affonso Romano de Sant'Anna (2000, 61), "há muitas variações da bipolaridade do EU, exemplificadas na fatura do sujeito submetido às pressões angustiantes do pensamento religioso. O UM originário desdobra-se não somente em um masculino e um feminino. Esse UM se desdobra num Eu satânico e num Eu divino".

Para Ismael Nery, o espírito do homem moderno caracterizava-se, sobretudo, pelo cansaço. O mal consistia em fazer-se uma construção de espírito dentro da ideia de tempo, que traz no seu bojo a corrupção e a destruição. As teorias políticas não solucionam o conflito entre espírito e matéria, nem o restabelecimento do equilíbrio que o homem vem perdendo gradativamente, desde que foi criado. O erro só poderá ser anulado com uma volta à raiz. "Não me conformo nem com o espaço nem com o tempo, / Nem com o limite de coisa alguma.", disse Ismael no seu poema Confissão (1933).

De Leopoldo Marechal, quando Adán Buenosayres veio a público, Julio Cortázar (1949) considerou o livro como um dos maiores acontecimentos nas letras argentinas, um livro que "precipita um aluvião desenfreado de imagens que escaparam de uma barragem que acabara de se romper". Para Cortázar, trata-se de uma novela autobiográfica. Mas a angústia existencial projeta a angústia da sua geração, enlaçada à visão de suas origens e expectativa de futuro. "Su angustia, que nace de desajuste, es en suma la que caracteriza - en todos los planos mentales, morales y del sentimiento - al argentino, y sobre todo al porteño azotado de vientos inconciliables".

Em Adán Buenosayres, a palavra angústia aparece 36 vezes. Angústia frente à tensão entre o tempo móvel das coisas terrenas e a eternidade do Universo; angústia ao abrir os olhos e deparar-se com coisas que lhe parecem estranhas, fantasmagóricas; um mundo povoado de imagens que assombram sem cessar o sono ou a vigília, memórias de tempos imemoriais, restos, ruínas; angústia frente às imagens da morte e odores de catacumbas que não param de açular seus pesadelos; angústia frente às imagens de rostos familiares que pairam distantes no tempo e no espaço. Mas em cada "despertar metafísico", que se dá pela

\footnotetext{
5 Todos os poemas de Ismael Nery citados estão publicados no Catálogo (1984, 26-39).
} 
manhã com o aparecimento do sol, ressurge a consciência restauradora que engloba a consciência do conflito e da busca de um ser novo que estava morto e renasceu: vai da queda de Adão ao nascimento do homem novo que encontrou o destino superior de sua alma. Na metafísica de Marechal, a queda é momento essencial, inerente à condição humana, para levantar e procurar o destino superior de sua alma.

Se a insônia de Adá Buenosayres era prolongada pelas "terribles imágenes de la destrucción" do Apocalipsis, era preciso despertar a inteligência para recompor a realidade e deixar de entregar-se ao pavor infantil, o medo da catástrofe. Cada episódio da viagem metafísica serve para Adán refletir sobre "a terra ferida e cicatrizada tantas vezes!" Mas, se todas as tradições recordam uma Idade de Ouro, reflete Adán, isso é prova de que ela existira um dia! Mas se existira, por que não deixou alguma recordação, um monumento, ruínas de cidades maravilhosas, indícios de uma enorme civilização? Sim. "A Idade de Ouro existira. Deixou um monumento, não na terra, mas na alma do homem. A mutilada estátua de uma felicidade que desde sua mutilação, queremos reconstruir em vão" (Marechal 1981, 150).

No Prólogo indispensável, no qual Marechal apresenta seu personagem, Adán acorda sentindo um sabor amargo, na língua do corpo e da alma. É um "despertar metafísico", declara o novelista. De olhos fechados, vê que o quarto está vazio, e lá fora não há nada também. Tudo se dissipou, tudo se dissolveu. "Que horror!" O mar evaporou, os astros se desprenderam. Mas ao abrir os olhos, viu que as coisas do quanto estavam ali e o mundo voltara à sua existência. Adán Buenosayres reflete: a rosa não murchara porque seguia vivendo em sua mente, não era tal qual a rosa que vira, mas como todas as rosas que haviam sido, eram e podiam vir a ser nesse mundo; a flor reduzida a número abstrato, a rosa emancipada do outono e da morte; de modo tal que se ele, Adan Buenosayres, fora eterno, também a flor seria em sua mente, ainda que todas as rosas exteriores acabassem, morressem e voltassem a florescer. (Marechal 1981, 9).

São muitas as chaves de leitura possíveis desse livro de Marechal, de 740 páginas, feito de ironias, metáforas e simbologias. Trata-se de uma alegoria da viagem da alma do ser humano, num movimento descendente para um posterior ascendente, até alcançar o divino, cujo eixo está centrado na cosmovisão do cristianismo platônico. Pela chave da metafísica, estética que, conforme o entendimento que estou tentando defender, contém traços para se refletir sobre o afeto da angústia na criação artística, percebe-se o movimento que vai da sensação de catástrofe à possibilidade da realização de uma poética e de uma ética para ressignificar a existência. O espaço narrativo da novela de Leopoldo Marechal contempla o estado de angústia de seu personagem, sobre a terra "ferido de morte", para exercer em diversos episódios o movimento da queda e da consciência restauradora. O herói de Adán Buenosayres, num deambular aparentemente sem rumo, reflete sobre o tempo e o espaço, sobre a origem divina do homem e sua queda, sobre a tensão entre finito e infinito, sobre a unidade inexorável entre matéria e espírito. A fragilidade do corpo, sua temporalidade, era compensada pela transcendência, permanência e essência da alma. 
Certo dia Adán Buenosayres resolveu dialogar consigo mesmo.

- Quem era ele, "essa entidade absurda", essa "enigmática besta racional, a difícil combinação entre um corpo mortal e uma alma imortal, o monstro dual cuja torpeza de gestos faz chorar aos anjos e rir aos demônios?

- É aquela que está submetida às duas condições limitativas: o espaço e o tempo, que o condenavam ao erro e à fadiga dos movimentos locais, ao devir e à morte.

- E o que fez Adán para livrar-se do terror do tempo e do espaço?

-Acreditou que sua alma não estava submetida nem ao tempo e nem ao espaço.

- Como percebe que a alma tem uma natureza caída?

-Por negação, percebendo os extravios de sua inteligência, o esquecimento de sua memória e as fraquezas de sua vontade; por afirmação, observando no exercício de suas potências algumas iluminações e arranques indefiníveis que considera vestígios de uma nobreza original perdida.

- Qual a razão daquele cansaço, rebelde a qualquer tratamento, de seu amigo o filósofo Samuel Tesler?

-Aquele cansaço incurável resulta das numerosas reencarnações que vem sofrendo desde a divisão do Hermafrodita original (Marechal 1981, 34-43).

A cada instante que se detém paralisado, na viagem, Adán/Marechal convoca a ideia de novos começos, à procura do que é durável, do que há de transcendente, do que é eterno, já que tudo o que é aparente desaparece em pouco tempo. É preciso encontrar a essência da verdade. Citando aqui Hannah Arendt, a consciência do tempo que transborda na angústia cria "essa picada de não-tempo aberta pela atividade do pensamento através do espaço-tempo de homens mortais e na qual o curso do pensamento, da recordação e da antecipação salva o que quer que toquem da ruína do tempo histórico e biográfico" (Arendt 1988, 31).

Essa é uma das chaves que abrem nossa compreensão da angústia dos artistas de concepção metafísica abordados aqui. A descoberta da finitude convoca a ideia da transcendência; a imagem da suspensão do tempo aponta para a procura do durável na essência das coisas; o terror do tempo e do espaço empurra a intuição a revelar a imortalidade da alma; o sentido da separação entre cosmo e vida humana produz a ânsia pelo realinhamento; a consciência da finitude do mundo das coisas terrenas desperta o desejo de reconciliação com o infinito, com o que há por trás das aparências; a ideia da queda do "homem" no mundo das trevas dá-lhe ânimo para seguir o caminho da ascensão ao mundo espiritual, das luzes e dos espaços divinos.

O conceito de angústia

O homem, pois, é síntese de alma e corpo, porém ao mesmo tempo, é uma síntese do temporal e do eterno (Kierkegaard 1968, 90).

Ao contrário do medo ou do pavor, "a angústia é sempre existencial" segundo Elizabeth Roudinesco (2019, 20). Grandes autores produziram considerável literatura psicanalítica sobre o tema. Em Freud, encontramos a noção de angústia da perda e da culpa; em Melanie Klein, sobre a angústia do despedaçamento; os teóricos da Self Psychology desenvolveram conceitos sobre a angústia da autodestruição; Lacan, "o mestre da angústia", que é, por sua vez, "profundamente angustiado", fez dessa o princípio fundamental da subjetividade humana (Roudinesco 2019, 21). 
Mas, a angústia, um dos pathos que marcam a modernidade, é tema também da filosofia. Rogério Miranda de Almeida (2019) mostra que há coincidência de intuição entre Freud, psicanalista, e Kierkegaard, filósofo e teólogo, na formulação do conceito de angústia, ao afirmarem que o objeto da angústia não é positivado, ou seja, diferente do medo e do susto que se apresentam diante de um fato concreto, o sujeito que se angustia não conhece o objeto da sua angústia. Em Kierkegaard, o objeto da angústia é o fato de não saber contra o que lutar. O "nada" é que dá nascimento à angústia. Em Freud (2019), o que angustia é a sensação psíquica de inquietante estranheza que coloca o sujeito num estado de prontidão reativa, como aparece no ensaio Das Unheimliche: algo deveria ficar oculto, mas vem à consciência; algo familiar é vivido com estranheza.

O conflito existencial no quadro da cultura ocidental tem raiz na tradição cristã (Agamben 2007, 28). O que se tinha por acídia, um estado de tristeza relativa à dignidade espiritual conferida por Deus, segundo Santo Tomás de Aquino, a ética capitalista tomou por desleixo e preguiça. "Os doutores da teologia não a concebiam por esse signo, mas sim sob o da angustiada tristeza e do desespero" (Agamben 2007, 28). A acídia seria uma fuga horrorizada diante daquilo que não pode ser evitado de modo algum, uma espécie de doença mortal, cuja imagem transtornada, Kierkegaard consagrou na descrição do "mais temível dos seus filhos: o desespero que está consciente de ser desespero, consciente, portanto, de ter um eu no qual há algo de eterno, e agora desesperadamente não quer ser ele mesmo, ou desesperadamente quer ser ele mesmo" (Agamben 2007, 28).

As exigências da modernidade criaram sujeitos autônomos, capazes de agir livremente para fazer jus ao uso da razão iluminista e da cidadania liberal. Porém, na cultura do corpo moderno, o poder de ação, a descoberta da capacidade de criação e autocriação, a concepção do humano como artifício, nietzschiano, ou racional, kantiano, se por um lado liberou o sujeito da razão da autoridade divina ou do poder autocrático, por outro, provocou um estado de angústia diante das possibilidades, controladas pelas políticas de Estado, ou escassas diante do potencial humano, ou porque agora requerem escolhas e atitudes éticas. Sob certa dimensão psicológica, aparece o medo do desmoronamento das identidades, já que nada é inexoravelmente fixo, tema que já trabalhei em outra ocasião a partir dos casos Schereber e Otto Weininger (Flores 2007).

Ou seja, a liberdade humana colocando o ser humano como feitor do mundo, em substituição ao deus demiurgo, trouxe o poder de lidar com a razão, mas também a responsabilidade de lidar com sensações, paixões, desejos, emoções e medos. Jean-Paul Sartre, outro mestre da angústia, segundo Roudinesco $(2019,21)$, "sabia que ter medo do que podemos fazer atesta o poder que a liberdade confere: e é aí que nasce a angústia autêntica." Sentindo-se condenado a viver nessa contínua tensão, entre razão e paixão, o ser humano percebeu no seu íntimo que não podia "estar em paz com a primeira, sem estar em guerra com a outra, permanentemente dividido, em conflito consigo mesmo”. Já Blaise Pascal (1973), em Pensamentos, expressara os mais apurados sentimentos de desespero, angústia, paixão, tragédia, num tono existencial, perante a precariedade da condição humana, da sua irremediável finitude.

Kierkegaard $(1968,29-41)$ salientou o aspecto concreto do homem como sofredor, em contraste com o conceito de homem racional, submetido ao sistema hegeliano, sistema no qual o indivíduo representa apenas um momento de uma totalidade sistemática que o ultrapassa e na qual, ao mesmo tempo, ele 
encontra sua realização. Em Kierkegaard há um forte sentimento de irredutibilidade do indivíduo, de sua especificidade e do caráter insuperável de sua realidade. Empreendeu, assim, Kierkegaard (1968, 15-19), a inaugural crítica à concepção racional hegeliana e positivista comtiana da humanidade. Para ele, o ser humano é dotado de possibilidades abertas em meio à liberdade de escolha, o que enseja uma dimensão ética do seu existir. A liberdade cria a angústia porque toca no verdadeiro problema da vida: descobrir quais são os verdadeiros tons e talentos de uma pessoa. Esse é o drama humano, marcado pela consciência individual em meio à angústia, exasperação e ansiedade. "A angústia é determinada pelo espírito sonhador (...) é a realidade da liberdade como puro possível. (...) por essa razão é que não a achamos no animal, cuja natureza não tem precisamente, a determinação espiritual” (Kierkegaard 1968, 45).

O filósofo teólogo dinamarquês abre, assim, o caminho para se pensar o ser humano como centro da reflexão filosófica da existência do dia-a-dia, abre o caminho para a "famosa análise" que empreende Martin Heidegger da "banalidade cotidiana e da caída na dimensão anônima e inautêntica do 'a gente', que acabou inspirando a caracterização de nossa existência nas sociedades de massa" (Agamben 2007, 26). Se para Kierkegaard, foi o pecado de Adão e Eva que os fez perceberem-se nus, habitantes comuns da terra que dominam e exploram seus recursos e os outros seres para sobreviver, Heidegger, fez do dasein (ser-a1), a forma de existência inautêntica, que marca a angústia do ser humano. O que determina a angústia é simplesmente o fato do homem se perceber como ser-no-mundo. Trata-se de um sentimento que, para Heidegger, não tem uma razão específica, simplesmente se manifesta como se o mundo tivesse perdido o seu sentido (Girola 2000, 8).

Por volta de 1910, a obra de Kierkegaard vai se tornando conhecida na Alemanha e depois em outras cidades europeias. O tema da angústia começa a fazer parte do vocabulário moderno, sob a filosofia trágica e irracionalista de uma angústia de Kierkegaard, do pessimismo de Schopenhauer, do homem do ressentimento de Nietzsche, da revolta de Rimbaud e de Latréamont, já presente na obra de Pascal. O tema da angústia pautou a produção de toda uma geração de poetas malditos, Baudelaire, Rimbaud, Mallarmé, Verlaine. Em 1891, cinco anos antes da morte de Rimbaud, o poeta da "impaciência, não apenas literária, mas existencial", a revista La Vogue divulga em Paris suas Illuminations. "Nascia a glória e a fama desse poeta, encarnação da poesia e do próprio pathos do homem moderno", e a cristalização da imagem do "poeta maldito" inaugurada por Baudelaire (Ivo 2004, 35).

Nas artes visuais o tema de angústia também se fazia notar, a exemplo da obra de Munch, uma pintura que desarmoniza nosso olhar diante da explosão de cores e de linhas errantes, fugidias, inconstantes, até inalcançáveis. Quando, em 2009, na minha primeira visita ao Museu Xul Solar, em Buenos Aires, para dar início à pesquisa, vi pendurada na parede Paisagem Bunti, obra de 1916, assaltou-me pela primeira vez a sensação de que havia ali ressonâncias do Grito de Munch, datada de 1883. Uma paisagem ameaçadora, uma ponte a ser atravessada, uma figura humana solitária. A partir daí, meus olhares se tornaram atentos aos sinais de angústia nas obras dos dois artistas místicos que faziam parte de meu projeto de pesquisa, naquele momento - Xul Solar e Ismael Nery. Dias depois, com a leitura de Adán Buenosayres, de Leopoldo Marechal, percebi que havia tocado num dos afetos que afligem vários dos artistas, poetas $\mathrm{e}$ escritores daquela quadra de pensamento e arte das primeiras décadas do século XX. 


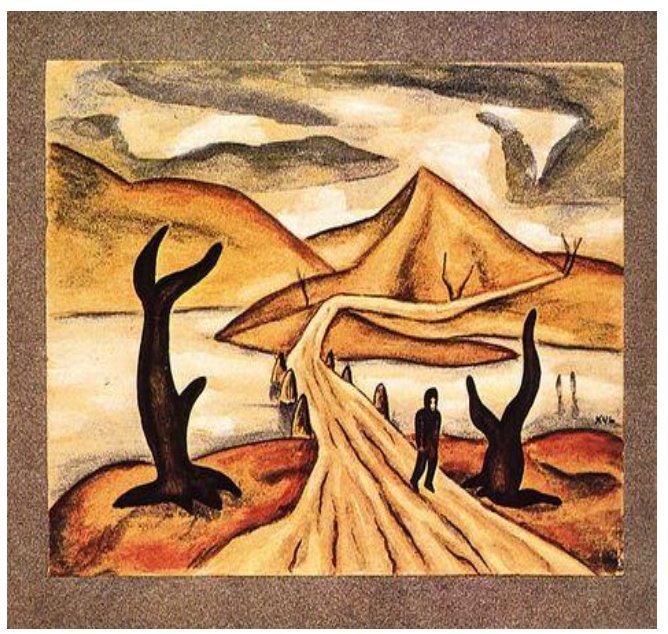

Figura 4: Xul Solar. Paisagem Bunti, 1916. Aquarela sobre papel. 15/25 cm Fonte: (Catálogo 1990, 52). (Derechos reservados Fundación Pan-Klub-Museo Xul Solar)

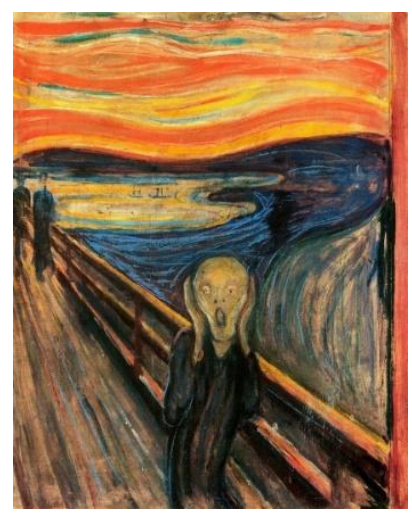

Figura 5: Edvard Munch. O grito. 1893. 91 x 73,5 cm

Óleo, pastel, cardboard, tempera. Localização: National Gallery, Oslo, Norway.

Fonte: Disponível em: https://www.wikiart.org/pt/edvard-munch/o-grito-1893

Acesso em: 08 ago. 2020

A angústia de Adão.

Pelo pecado de Adão, a pecabilidade penetrou no mundo...

(Kierkegaard 1968, 72).

Por que esses loucos estão gritando? Do que eles têm medo? Você ainda não entende que este mundo está uma bagunça desde que Adão e Eva fizeram essa safadeza com Deus no Paraíso? (Marechal 2013, 53). ${ }^{6}$

A abordagem da angústia de Adán Buenosayres, protagonista da epopeia de Leopoldo Marechal, no cruzamento entre a novela do poeta e a arte visual de Xul Solar e de Ismael Nery, alçados a signos da angústia de Adão na América, requer que retornemos por um momento ao conceito de angústia de Soren Kierkegaard. Não que os três artistas tenham lido o filósofo teólogo dinamarquês ${ }^{7}$. Tudo

\footnotetext{
${ }^{6}$ ¿Por qué gritan estos locos? ¿De qué se asustan? ¿No comprenden todavía que este mundo es un bochinche desde que Adán y Eva le hicieron a Dios aquella porquería en el Paraíso?

${ }^{7}$ No começo do século XX, as obras de Kierkegaard não eram conhecidas ou ainda eram bem pouco lidas. Rogério Miranda de Almeida (2019), ao falar da coincidência entre o filósofo dinamarquês e o pai da psicanálise vienense, na conceituação do afeto da angústia, afirma que Freud jamais leu Kierkegaard.
} 
indica que os três artistas não leram Kierkegaard, pelo menos até o momento da produção das obras aqui discutidas. No entanto, foram incansáveis leitores da Bíblia, o livro que influenciou profundamente o pensamento ocidental e, é nele, que o filósofo dinamarquês foi buscar os elementos para formular o conceito de angústia.

O que é pertinente aqui, nessa sessão do artigo, é considerar a apropriação que Kierkegaard fez dos dogmas do cristianismo, especialmente do pecado original, que plasmou o sentimento de culpa e de perda do Paraíso, fundamento da "ética da existência" cristã. "A Ética pagã desconhecia o pecado, a cristã acrescenta em seus domínios a realidade do pecado" (Kierkegaard 1968, 28). Para o filósofo teólogo, o problema da hereditariedade do pecado original está na própria essência da existência humana. Pelo pecado de Adão, um indivíduo é ele e ao mesmo tempo toda a humanidade. “... a humanidade participa toda inteira do indivíduo, do mesmo modo que o indivíduo participa de todo o gênero humano". Desse modo, qualquer indivíduo é afetado, na sua essência, pela história de todos.

\begin{abstract}
A perfeição pessoal reside, pois, em participar desinibidamente na totalidade. A nenhum indivíduo é indiferente a história da humanidade, assim como a esta, não é indiferente a história de um indivíduo. Adão é o primeiro homem, e isto significa que ele é simultaneamente ele mesmo e o gênero humano. (...) Por isso, aquilo que dá a explicação de Adão dá igualmente a explicação do gênero humano, e reciprocamente (Kierkegaard 1968, 33).
\end{abstract}

Como consequência do pecado original (na história do cristianismo, a atribuição do peso da culpa do pecado oscila, entre Adão e Eva, dependendo da interpretação teológica), a humanidade herdou a culpa imbricada ao ethos moralizante que permeia a história sobre a origem do homem escrita pelos hebreus (Greenblatt 2018). Para Agostinho, segundo Stephen Greenblatt (2018, 103-105), a maneira como nos reproduzimos, pelo intercurso sexual (o grande problema que Augustinho tentou resolver: como gerar filhos sem as excitações sexuais), foi corrompida por Adão e Eva. Em decorrência disso, há algo de essencialmente errado conosco, pois todo nascimento se origina do pecado do sexo, uma herança inescapável que, embora seja herança, não nos exime da culpa. "Toda a nossa espécie é aquilo que Agostinho chamava de massa pecati, um acúmulo de pecados".

Para (Kierkegaard 1968, 37), Cristo é o único indivíduo que ultrapassa a individualidade; por essa razão, igualmente, surge não no princípio, porém na plenitude dos tempos. A imagem do afastamento de Deus, com a queda do Paraíso, provocara, assim, a forma mais profunda de angústia, no sentido bíblico, pois remete a uma situação existencial de desamparo total. Este abandono se manifesta também com o grito paradoxal de Jesus na Cruz: "Meu Deus, meu Deus, por que me abandonastes?" (Girola 2000, 13). Trata-se do sofrimento de um justo, abandonado por Deus à mercê de seus inimigos; trata-se de uma contradição: Deus clamando pelo abandono de Deus. Esse paradoxo marca a teologia cristã. Deus, o supremo objeto de desejo, parece ter abandonado sua criatura, produzindo a dúvida do sentido da própria existência e, com ela se reinstaurando o sentimento de culpa. 
Na interpretação de Roberto Girola (2000, 9), Kierkegaard considera que existem três opções de vida: a estética, a ética e a religiosa. Numa terminologia freudiana, na primeira opção, o homem vive entregue à sua libido; na segunda, é dominado pelo superego; na terceira prevalece a sublimação da fé. "A dimensão estética (da libido) é caracterizada por uma vida mergulhada na plenitude do momento, voltada para capturar o gozo da existência, embalada na 'valsa do instante', uma situação 'na qual não aspira a nada, não deseja nada". Este tipo de existência, marcada pela mudança e imediatismo, leva à experiência do desespero. É preciso fugir do estágio estético da vida, é preciso fugir da prisão dos desejos. O homem deve aspirar, num "salto", o estágio ético, ${ }^{8}$ que o leva a um estágio de interioridade, constância, fidelidade e compromisso.

Seguindo ainda com o psicanalista Roberto Girola, o conflito que existe no quadro da cultura ocidental deve muito à leitura da Bíblia, repleta de imagens portadoras de ansiedade, sentimento de culpa, de desespero e de angústia. $\mathrm{Na}$ própria leitura da Bíblia, diz Girola, é possível identificar uma associação da palavra angústia com as seguintes situações: perigo externo iminente, perigo de morte, num sentido próximo ao que Freud concebe como angústia realista. $\mathrm{Na}$ Tradução Ecumênica da Bíblia, uma versão portuguesa que, seguindo o padrão da versão francesa, se caracteriza por uma tradução mais próxima do original grego e hebraico, a palavra angústia é usada 56 vezes, no singular, e 16 vezes, no plural. A palavra ansiedade recorre 2 vezes. Por trás da palavra angústia/ansiedade encontramos a raiz hebraica çar que significa perigo, risco, aperto, apuro, aflição, angústia. Às vezes, na Bíblia, o termo angústia é associado à palavra "treva(s)", entendida como ausência total de luz, que evoca o caos primitivo, o lugar onde operam o mal e a morte (Girola 2000, 12).

Como já se mencionou acima, nenhum dos três artistas - Xul, Ismael e Leopoldo - leu Kierkergaard. Contudo, indiretamente, encontra-se neles a linguagem e as marcas da cosmovisão do teólogo dinamarquês, absorvidas na fonte comum, a Bíblia cristã. De Ismael Nery, os companheiros do grupo dos modernistas do Rio de Janeiro, que frequentavam sua casa, relatam que ele era leitor assíduo da Bíblia, desde a infância. Seu sistema filosófico, sistematizado como Essencialismo, prega uma espécie de catolicismo reformado, com base no cristianismo primitivo, a partir de uma leitura muito particular do Evangelho de São João, do pensamento de Santo Agostinho e de Santo Tomás de Aquino, além da leitura de Nietzsche e dos pré-socráticos. Um cristianismo para ser vivido no dia-a-dia, concretamente. Antônio Bento (1973, 43) diz que para Ismael, a Bíblia resumia tudo quanto existia de mais profundo na produção literária. A leitura do Eclesiastes concorria para acentuar ainda mais o tom pessimista de suas ideias. A filosofia tomista exercia especial atração sobre seu espírito, dado a longas e contínuas meditações.

Xul Solar estudou várias religiões, práticas exotéricas, alquímicas, astrologia, leu a obra teosófica de Helena Blavatsky. O estudo da antroposofia de Rudolf Steiner deixou marcas em Xul (Albós 2004, 98). Quando voltou da Europa, em 1924, Xul trouxe para a Argentina 30 livros de autoria de Steiner ou sobre Steiner. Da antroposofia desse mestre, interessava a Xul, especialmente, a teoria das cores de Goethe, que interrelaciona a gama cromática com a simbologia religiosa. Também lhe interessavam as ideias de Steiner sobre arquitetura como síntese suprema dos conteúdos filosóficos, artísticos e religiosos (Albós 2004, 100). Em 1923, ano em que assistiu em Stuttgart a várias

\footnotetext{
${ }^{8}$ Kierkegaard não estabelecera qual dessas vidas possíveis seria melhor, mas é evidente - diz Girola $(2000,12)$ - que o ele se mostraria inclinado para enaltecer o caminho do religioso, a sublimação da fé.
} 
conferências de Rudolf Steiner, Xul pintou aquarela cristológica, Jefe Honra, cujos olhos cheios de estupor nos impressionam, num rosto de Cristo crivado de espinhos. A figura de Cristo foi tema reiterado no pensamento de Steiner. O verdadeiro cristianismo, dizia Steiner, é uma vivência que se expressa através de uma experiência pessoal. Steiner enfatizava que, com o passar dos tempos, mais gente poderia viver como Cristo, como ser espiritual, independente de toda igreja (Albós 2004, 101).

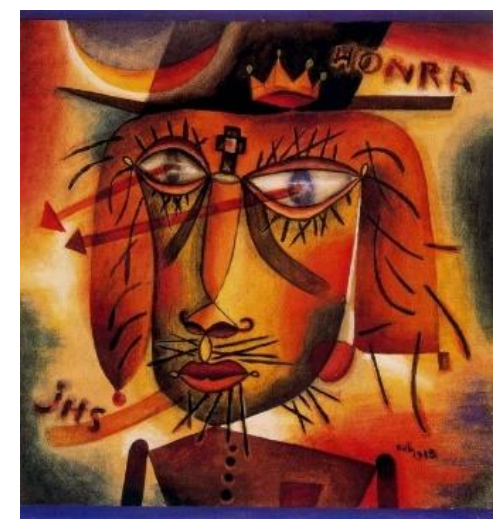

Figura 6: Xul Solar. Jefe Honra, 1923. Aquarela sobre papel. 28 X $26 \mathrm{~cm}$ Fonte: (Gradowczyk 1994, 89)

A novela de Leopoldo Marechal toca no mais profundo âmago da cosmovisão bíblica. Em uma das passagens de Adán Buenosayres, o protagonista atribui à leitura da Bíblia seu estado de angústia, suas insônias e seu despertar cheio de imagens e premonições.

\footnotetext{
Leía en el Viejo Testamento la paciencia de Dios y la locura de los hombres: historias de amor y odio, virtudes admirables y vicios tremendos, alegrías patriarcales y llantos de miseria, terremotos y diluvios, pestes y masacres desfilaban ante sus ojos... (Marechal 2013, 53).
}

Graciela Maturo $(1999,218)$, ao se debruçar sobre as bases intelectuais da obra literária de Marechal, mostra as diversas fontes do escritor, começando pelas clássicas - Platão, Homero, entre outras -, e passando pelas modernas, de filosofia e teologia, de poesia e literatura, adentrando o romantismo, o simbolismo, os decadentistas, entre outras fontes. Os "textos bíblicos foram permanentemente relidos", pelo poeta, diz a autora. Na segunda viagem que fez à Europa, em 1929, Marechal dedicou-se a estudar as linhas filosóficas de PlatãoSanto Agostinho e de Aristóteles-Santo Tomás de Aquino. E foi quando deu início ao plano de Adán Buenosayres.

$\mathrm{Na}$ exegese que fez dessa obra, Maturo $(1999,252)$ afirma que o complexo simbólico central no pensamento do poeta é formado pelas figuras de Adão, Gênesis, Paraíso, Queda, Inferno, Amanhecer Metafísico ou Ressurreição. Adão teria sido o primeiro poeta. Eva, transformada em mulher natural, é a mãe do gênero humano; em mulher sobrenatural, é a celestial Porta do Céu. O Paraíso é o lugar da aurora, do qual o ser humano foi arrancado, segundo o Gênesis, pelo pecado e a queda. O Inferno, tal como em Dante, é o mundo da prova e da passagem, e não o inferno absoluto da privação do Ser. É o contraponto do Paraíso, mas contém a porta para a saída do mundo decaído. O desenho do Inferno, em Calcodelphia, é o de uma cova em espiral invertida, com um caminho labiríntico, difícil e intrincado a ser percorrido, até alcançar no 
ápice do cone a passagem para a nova comunidade que, como já mencionamos, seria a comunidade organizada pelo governo de Peron.

Em síntese, a aplicação estética dos três artistas discutidos aqui contempla a valorização da tradição da cultura ocidental, a viagem espiritual na procura das origens divinas do ser humano, para a criação de um novo-mundo, um novo-ser, com base na tradição judaico-cristã, platônica-aristotélica, embora Xul Solar pregasse a verdade de todos os deuses e se dedicasse a perscrutar os ensinamentos divinos na cabala judaica, nos mitos e em todas as grandes religiões.

Uma estética decolonial anunciada?

... para Fanon, a colonização das subjetividades produz patologias (...), de modo que nenhuma revolução poderia acontecer sem a descolonização do pensamento. (Felinto 2020).

Ao se considerar que os três artistas latino-americanos, aqui abordados, expressam uma linguagem artística que denota o ethos agônico frente ao presente, se poderia imaginar que estivéssemos diante de uma estética que primasse pela superação da modernidade herdada no processo da colonização europeia.

Conforme as reflexões epistemológicas que aparecem no chamado giro decolonials desenvolvidas pelos teóricos do pensamento decolonial como radicalização dos argumentos dos Estudos pós-coloniais, a colonização europeia fez muito mais do que apenas manipular os instrumentos de poder para explorar os recursos da terra e da mão de obra nativa - a indígena e a africana arrancada da África e transferida para a América. O grupo Modernidade/Colonialidade, fundado em 1998 na Universidad Central de Venezuela, com a presença de Castro-Gómez, Walter Mignolo, Aníbal Quijano, Enrique Dussel, Edgardo Lander, entre outros, imprimiu o termo colonialidade, como algo que faltava aos Estudos Pós-Coloniais, para argumentar no sentido de mostrar que a dominação europeia pelos processos de colonização ancorou-se numa tripla dimensão: a do poder, do saber e do ser. Pedro Gómez e Walter Mignolo $(2012,8)$ sugerem que "a matriz colonial do poder é uma estrutura complexa de níveis entrelaçados". Abarca não somente o controle da economia política e da natureza, mas também das subjetividades e do conhecimento. Para entendermos nossas culturas colonizadas, há que se considerar as duplas faces do processo: modernidade/colonialidade. A colonização foi parte intrínseca à modernidade europeia. O sucesso da colonização dá-se na medida em que os povos dominados incorporam as subjetividades modernas. A decolonialidade seria, então, uma ação epistêmica, teórica e política com o objetivo de superar a colonialidade do moderno.

O importante, aqui, é não perdermos de vista a integralidade do tripé da colonialidade, e ver que um de seu suporte está centrado no poder de manipular (fabricar) subjetividades, o que envolve questões de raça, gênero, desigualdade social, regimes epistêmicos referentes ao domínio das ciências, das instituições, da circulação e da distribuição dos lugares de saberes e de dizeres. Nesse sentido, ou seja, no âmbito da subjetividade ou no âmbito da criação do ser colonizado, as culturas artísticas jogaram importante papel. Como defendem Pedro Gómez e Walter Mignolo $(2012,9)$, "Las culturas artísticas (y con ello nos referimos a todo el complejo que suscita y convoca la creación de una obra) forman parte de la matriz colonial de poder en los procesos de manejar y manipular subjetividades." Portanto, há de afirmar-se, com ênfase, que no quadro das artes inserem-se importantes espaços de subversão, ou seja, de desobediência epistêmica na produção de experiências e subjetividades a partir do desejo do 
próprio, do colonizado, e não do outro, do colonizador "El carácter decolonial [da arte] no es inherente a un objeto, una obra, una práctica, una persona o un grupo, sino a un modo de ser, sentir, pensar y hacer en una situación determinada, enfrentando en algunas de sus caras o dimensiones la matriz colonial del poder".

A operação estética, que vimos apresentando ao longo desse artigo, trabalhada por Leopoldo Marechal, Xul Solar e Ismael Nery, contempla o desconforto espiritual frente à noção de tempo e espaço modernos e à dimensão materialista, racional e pragmática do capitalismo, ou seja, tudo o que recebemos no processo modernidade/colonialidade. Contudo, o que eles defendem, não é o "resgate" das culturas não colonizadas ou pré-coloniais. Se na arte metafísica que praticaram, referências nacionais ou citações do passado "arcaico" da nação ou do continente são identificadas nas obras desses três artistas - Xul, Ismael, Leopoldo -, inclusive ambientadas localmente - o ambiente de Adán Buenosayres é totalmente portenho; os quadros da fase neocriolla de Xul Solar configuram signos da cultura asteca pré-colombiana; algumas obras de Ismael Nery apresentam traços do Rio de Janeiro -, há um alcance maior nessa operação estética. A citação do "passado" ou a "busca do arcaico" que se incorpora na arte pictórica de Ismael e Xul e na épica de Leopoldo Marechal extrapola as raízes locais, nacionais, nos impossibilitando considerá-las insights decoloniais, na acepção que levantamos acima. A aplicação estética dos três contempla o retorno à tradição da cultura ocidental, trata-se de uma viagem espiritual à procura das origens divinas do ser humano.

Se não se pode classificá-los, sem risco de reducionismos, como representantes da arte metafísica, na linha de Giorgio de Chirico e Carlos Carrá (o essencialismo de Ismael Nery e o misticismo de Xul Solar não encontram lugar nas chaves classificatórias dos estilos ou escolas), muitos dos aspectos abordados para argumentar em favor de uma estética da angústia fazem ressonância com linguagem metafísica. Sobre Leopoldo Marechal, a aproximação com a estética metafísica é mais contundente, claramente definida. Graciela Maturo (1999, 35), no capítulo III do livro Marechal, el caminho de la beleza, analisa artigos, ensaios e obras do poeta argentino, que "aportan distintos aspectos de la teoria metafísica marechaliana”.

Maria Elisa Linardi Cezaretti (1994) ao analisar a arte de quatro artistas - dois brasileiros (Tarsila do Amaral e Ismael Nery) e dois argentinos (Emílio Petorutti e Xul Solar), concluiu que há uma convergência da angústia do ser latino-americano com o momento de aspiração à modernidade. Como representantes da arte metafísica na América, apresentam uma especificidade em relação à Europa, diz a autora, que se encontra na citação do próprio passado local ou nativista, com acento na pátria ou nos mitos arcaicos do país. E essas se misturam aos temas universais recorrentes na arte metafísica europeia. 
O que se pode afirmar, é que a estética da angústia expressa na arte metafísica, mostrada ao longo desse artigo, visava transcender o peculiar presente do ser brasileiro ou argentino, ou latino-americano, não para negar a modernidade ou para "resgatar" memórias e experiências soterradas pela colonialidade, mas como um movimento mais amplo, concomitante ao que acontecia na Europa, contra a exclusividade da razão, do materialismo e positivismo. A arte metafísica era a linguagem estética que ajudava o artista agônico a cercar-se de Deus e a conectar os fios partidos de uma suposta unidade perdida no tempo remoto do Paraíso bíblico, da idade de ouro ou da infância da humanidade, com base no conhecimento místico, ou conhecimento que ultrapassasse a realidade contingente e ajudasse encontrar a essência do universo cósmico, eterno e transcendente.

$\mathrm{O}$ ato artístico abordado aqui não traz, portanto, a potência de romper os laços com a matriz colonial. O interesse pelos temas do passado faz parte do esforço para encontrar a linguagem simbólica do mundo ancestral, internamente, tal como os europeus fizeram ao dirigir-se para fora da Europa. Há que se considerar que havia de comum com os europeus o corpus de erudição e a aprendizagem das linguagens estéticas, num momento especial que fez com que latino-americanos se igualassem em indagações e propostas de seus contemporâneos da metrópole. Os jovens latino-americanos, intelectuais, artistas, poetas, na grande maioria viajaram para a Europa, ou tomavam contato com o que chegava no país vindo do estrangeiro. Quem não viajou, como foi o caso de Mário de Andrade, tomava contato com a literatura europeia. Da Europa, chegavam, geralmente na tradução francesa, mas lia-se também em inglês, alemão ou italiano, obras de Pascal, Dostoievski, Tolstói, Ibsen, Schopenhauer, Nietzsche, Rimbaud, Baudelaire, Latréamont, Kafka, Spengler, Bergson, Freud, Keyserling. De uma forma ou de outra, a intelectualidade letrada da Argentina e do Brasil, como de resto de toda a América Latina, era formada naquela quadra de pensamento que problematizou as sensibilidades humanas: do pessimismo de Schopenhauer, do homem do ressentimento de Nietzsche, da revolta de Rimbaud e de Latréamont, do medo do declínio do Ocidente de Spengler, da incerteza do inconsciente de Freud, e do Dasein de Heidegger, mostrando que o humano é na medida da sua existência cotidiana.

Xul Solar era portador de uma cultura erudita. A mãe italiana, Agustina Solari, e o pai, alemão, Emílio Schulz, engenheiro, culto, e que trazia na bagagem, além de livros, "álbuns musicais manuscritos que permite imaginar o tipo de repertório que lhe interessava" (Cristiá 2007, 25). Com a idade de 24 anos, Xul foi para a Europa e lá permaneceu por doze anos (1912-1924), passando temporadas em Londres, Paris, Florença, Milão, Turim e Munique, em meio ao revival espiritual do programa estético de Kandinsky e Franz Marc, o que lhe possibilitou contatos com a estética de inspiração teosófica de Mondrian, com o misticismo religioso e messiânico que atravessa a teoria e a prática pictórica de Malevich e com as associações entre música e cores de Paul Klee.

Ismael Nery, de descendência portuguesa, holandesa e índia, nasceu em Belém do Pará, filho de um médico famoso, oficial da Marinha, na patente de Capitão da Fragata que morreu aos 33 anos de idade, de um ataque cardíaco, a bordo do navio quando voltava de um Congresso em Copenhague. Com a morte do pai, Ismael com a idade 9 anos transfere-se com a mãe para Rio de Janeiro, para juntar-se à família materna que era dona de várias propriedades na cidade (Cordeiro 2003, 8). No Rio, estudou na Academia de Belas Artes e frequentou o curso de Arquitetura. Em 1921, Ismael viajou para a Europa, onde permaneceu por um ano, na França e na Itália. Matriculou-se na Academia Julien, de Paris. E 
vai também ao Oriente Médio visitar as Terras Santas, em companhia da mãe, que era mística. Em 1927, faz sua segunda viagem à Europa. Conhece André Breton, o principal teórico do surrealismo e entra em contato com a produção artística de Chagall e Miró.

Os avós paternos de Leopoldo Marechal eram franceses que emigraram para o Uruguai. O avô era natural de Paris e havia lutado na Comuna. Dele, Marechal herdou o gosto pela leitura e o fervor revolucionário. Os avós maternos eram espanhóis. O avô dado à poesia. (Maturo 1999, 26). Conta Graciela Maturo $(1999,25)$ que na biblioteca de Marechal viu várias edições da Bíblia, 6 tomos de Platão em francês, 2 tomos de Heródoto, as obras completas de Homero, Tertuliano, Horácio e Virgílio, Confissões de Santo Agostinho, e muitos outros clássicos do mundo antigo e dos teólogos e de santos da igreja. Havia Pascal, Montaigne, Joyce. Livros de filosofia, de ciências e história. Livros de sabedoria oriental, enciclopédias. "En suma, sin tratarse de un repositorio numéricamente cuantioso, era la biblioteca siempre consultada de un cristiano humanista, nutrido en las fuentes clásicas, fiel a sus maestros y abiertos a la problemática de su tiempo". Em 1926, Marechal viajou a Madrid e de lá foi a Paris. Além de encontrar diversos amigos intelectuais e artistas argentinos que lá se encontravam, esteve com Picasso e Unamuno, assim como com o grupo dos surrealistas. "Sus amigos plásticos lo ayudaban a descubrir los secretos de la armonía clásica: releía metódicamente las epopeyas, estudiaba las líneas filosóficas de Platón-San Agustín y Aristóteles-Santo Tomás de Aquino" (Maturo 1999, 29).

Portanto, o ideal da linguagem metafísica praticada na América, dentro do escopo do ethos agônico, era concomitante ao europeu. No entorno da passagem do século XIX para o XX, a tese da Decadência do Ocidente gerou um movimento espiritual que pregava uma espécie de "retorno" ao passado da humanidade, à procura de mitos e culturas "primitivas", de elos "perdidos" que religassem o "homem" às suas origens adâmicas, à infância da humanidade perdida com a queda do Paraíso. As artes de vanguarda (desde Van Gogh e Gauguin a Derain, Matisse, Picasso, Kandinsky, Franz Marc, Brancusi), procuravam fora da Europa (na arte do Extremo Oriente, da tribal africana ou do Egito, nos entalhes neolíticos, nas culturas pré-colombianas, nas religiões orientais ou no cristianismo da Idade Média, nas culturas transformadas em folclore), referência para suas experimentações formais artísticas.

$\mathrm{Na}$ América do Sul, o movimento apresenta-se com a dupla face do Jano: uma voltada para "fora", para a Europa e para o futuro, tanto no que se refere ao uso das linguagens formais artísticas, quanto à atualização das referências teóricas; outra, voltada para "dentro", para o seu próprio passado. Contudo, esse interesse pelo passado da nação ou do continente significava a procura de elementos locais para, a partir daí, alçar voos para alcançar o universo, para contribuir no ideal de um "novo mundo", um "novo homem", ideário da "matriz", da metrópole, naquele pós-primeira guerra mundial.

\footnotetext{
9 Embora tivesse origem indígena, Ismael ressaltou suas feições indígenas apenas no Autorretrato de 1927, mostrado acima. Ele achava que o modernismo brasileiro dedicado a temas nacionais estava se inclinando para o anedótico e a superficialidade. Os mexicanos talvez tivessem razão para pintar o índio, dizia, pois que o elemento autóctone via-se entrosado na sociedade, ao passo que no Brasil, o índio era visto no cinema de Hollywood. Quanto ao negro, ele achava que somente a sensibilidade negra poderia expressá-lo. A arte brasileira deveria construir-se no plano universal.
} 
O nome da novela de Leopoldo Marechal leva o nome do "primeiro pai". A presença desse mito e de sua companheira Eva era recorrente na arte de vanguarda. Marc Chagall, inspiração de Ismael Nery, pintou pelo menos 16 vezes o casal adâmico. $\mathrm{Na}$ arte dos pré-rafaelitas, fonte dos místicos modernistas, William Blake fez 10 pinturas de Adão e Eva. Gauguin representou o casal adâmico e mais três Evas, ambientados na Polinésia. Há 5 obras do primeiro casal realizadas no surrealismo de Salvador Dali. Adão e Eva aparecem gordinhos e gordinhas na pintura de Botero. Também aparecem dourados no simbolismo de Gustav Klimt. Graciela Maturo $(1999,120)$ lembra que o tema América-Paraíso, gravado no imaginário, é retomado pelos modernistas e vanguardistas na Argentina. Lugones e Darío trabalharam o tema e Vicente Huidobro também criou seu Adão.

Ismael Nery tinha obsessão pelo desenho de casais, cujos corpos misturados entrelaçados davam uma ideia de que os primeiros humanos tinham sido andróginos, nem homem nem mulher, eram um só ser. A divisão dos sexos teria sido consequência da queda. No desenho Pecado original, vemos um movimento em diástole, para fora: os pés e os membros inferiores das três figuras - a mulher, o homem e a árvore antropomórfica -, ainda se encontram unidos, porém, em posição de avançar. Eva agarrada às costas de Adão, o quadro retrata os segundos que antecedem a queda do "homem", a separação da natureza, a maldição da divisão dos sexos e a perda do Paraíso.

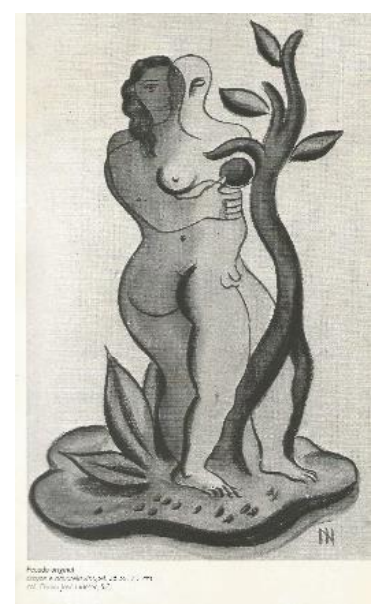

Figura 8: Ismael Nery, Pecado Original, s/d., crayon e aquarela s/papel, 26,5×17,2 cm Coleção particular Chaim José Hamer, S Fonte: (Catálogo, 1984, 161)

Na obra de Xul Solar, não encontrei Adão e Eva representados, mas a serpente aparece em diversas imagens, carreando diversos símbolos, especialmente nas pinturas que integram o que se conhece como seu ciclo americano - 1923-1927 -, plenas de referências pré-colombianas. Acreditava, Xul, que a América, com seus sistemas de mitos e crenças, podia dar "al mundo convulsionado un gran ejemplo de convivencia, de confraternidad, de mutuo respecto, sobre todo entre los países de origen latino" (Sheerwood 2005, 76). Seu desejo criollista era levar "Al mundo cansado, aportar un sentido nuevo, una vida más múltiple y más alta..." Seu patriotismo era encontrar "el más alto ideal posible de humanidá - realizarlo y extenderlo al mundo” (Xul Solar 2005, 99). 


\section{À GUISA DE CONCLUSÃo}

$\mathrm{Na}$ epopeia de Leopoldo Marechal, ambientada na Buenos Ayres dos anos de 1920, Adán, antonomásia do próprio autor (uma novela autobiográfica), é o herói, aquele que conduz as outras personagens, todas reconhecidas como representações dos antigos companheiros do movimento da vanguarda criollista (congênere do modernismo antropofágico brasileiro, embora com especificidades próprias), em torno da Revista Proa (1922-1923) e da Martin Fierro (1924-1927): Jorge Luis Borges, Norah Borges, Jacobo Fijman, Raul Scalabrini Ortíz, Xul Solar, Oliverio Girondo, Raúl González Tuñon, Macedônio Fernández, Eduardo González Lanuza. O autor, Leopoldo Marechal, "viveu as peripécias dessa vanguarda argentina, de tônica vitalista e criollista, mas logo produziu uma paulatina conversão, de índole espiritual e religiosa, assumindo um cristianismo militante." (Maturo 1999, 30).

Renata Rocco-Cuzzi $(2004,462)$ cita uma das resenhas do livro, que saiu logo após a publicação em 1948: "Leopoldo Marechal: Adán Buenosayres, un iracundo (irado) análisis por parte de quien había pertencido a la vanguardia mantinfierrista". ${ }^{10}$ Rocco-Cuzzi $(2004,464)$ levanta a seguinte questão: por que Marechal insiste em definir o livro como epopeia? Por que o caráter épico da viagem como descobrimento de territórios desconhecidos? "O périplo que faz a Saavedra [bairro nos arredores de Buenos Aires], pode ler-se - responde a autora - em duas dimensões: como a destituição do criolismo e a depuração de seus companheiros da Revista Matin Fierro; e também como reescrita do passado mítico nacional na chave da paródia." Por outro lado, as personagens, ironizadas, aqueles antigos companheiros, agora "sujeitos que desviam o povo de seu destino: os irresponsáveis políticos, os corruptos, os intelectuais, os que alijam o bem do caminho verdadeiro, põem em palavras as pretensões do autor de atuar como o condutor da travessia para a verdade".

Segundo Rocco-Cuzzi (2004, 462), o próprio Marechal em certa ocasião, declarou: "Soy retrógrado, pero no un 'oscurantista', ya que voy, precisamente, de la obscuridad a la luz". O retrógrado para Marechal, vai de uma conotação negativa para uma qualificação positiva, no sentido de melhoramento, no sentido de chegar a uma sorte de lugar de excelência, na projeção do futuro que vai "de la oscuridad a la luz", ou seja, da confusão à verdade. Definitivamente, diz a autora, Adán Buenosayres é o eleito para protagonizar a viagem espiritual que Marechal considera ser seu atributo de herói diante das ações risíveis das outras personagens.

${ }^{10} \mathrm{O}$ peronismo de Marechal foi ao ponto de se tornarem inimigos, ele e Borges. Enquanto Marechal trabalhava para levar Peron ao poder, Jorge Luis Borges, entre muitos artistas e intelectuais, assinou o manifesto, em 1946, em prol da União Democrática, adversária de Perón. Embora Xul Solar não tivesse assinado o manifesto de 1946 e nem a lista de 1928, na qual estava Borges, a favor da reeleição Hipólito Yrigoyen, os dois, Xul e Borges continuaram amigos. Xul Solar praticamente não se envolveu com a política. (Albós 2004, 244-246). 
Diferente da interpretação de Beatriz Sarlo (2002), que considera que Marechal, com sua representação, homenageia a Xul Solar na novela Adán Buenosayres, Renata Rocco-Cuzzi (2004, 464), pelo contrário, afirma que o périplo a Saavedra, é "una destitución del criollismo y uma depuración de sus compañeros de la gesta martinfierrista" (2004, 464). O personagem Luis Pereda, tido como "fortachón y bamboleante como un jabalí ciego", representa Jorge Luis Borges, um dos companheiros martinfierristas tratado com "más saña", na "voz irónica" do narrador Adán Buenosayres. A Luis Pereda/Borges é atribuída o papel de teórico do criollismo; e ao astrólogo Schultze/Xul Solar, o inventor do neo-criollo (Rocco-Cuzzi 2004, 471).

A certa altura da novela, Adán dirige-se a Luis Pereda/Borges e lhe declara: "Soy um argentino en esperanza". No momento Adán não podia solidarizar-se com a realidade do país. Mas tinha esperança de religar os fios dos valores e da tradição que seus avós tinham cortado ao saírem da Europa e se instalado na nova pátria. “... a mí me toca reanudar ese hilo y reconstruirme según los valores de mi raza. En eso ando. Y me parece que cuando todos hagan lo mismo el país tendrá una forma espiritual" (Marechal 2013, 87). Maturo (1999, 126) considera que Adán Buenosayres é o espaço narrativo do acesso a ipseidade, que esteticamente caracteriza como presente de um ser novo, que estava morto e renasceu: Adão, Cristo, o Homem Novo. A posição de Marechal, como a de Dante, afirmou-se na prioridade da queda. O homem deve perder-se no labirinto do mundo para encontrar o destino superior de sua alma. Perder-se para reencontrar-se, palavra do Evangelho (Maturo 1999, 35).

Ninguém aqui escapou ao etnocentrismo cultural. Ou como disse Borges, "nada pode evitar a influência deste livro [Bíblia] e as consequências que ele forjou. (Apud. Lopez-Pedraza 1997, 34). Rafael López-Pedraza, psicanalista junguiano e professor de mitologia na Escola de Letras da Universidade Central da Venezuela, levanta questão pertinente para irmos encerrando por aqui: a estética da angústia, abordada ao longo desse artigo, tem raiz na civilização ocidental e, como tal, é componente intrínseco do processo modernidade/colonialidade. Dessa feita, não contém gérmens que induzam a uma prática decolonial.

A ansiedade cultural, que se dá no plano psíquico no quadro da civilização, segundo Lopez-Pedraza, está fundada no conflito ante à "imposição" do monoteísmo bíblico sobre a visão politeísta do imaginário religioso pagão. Quais as implicações que essa imposição tem sobre a cultura ocidental e, em particular no quadro da colonização? $\mathrm{O}$ autor parte do pressuposto de que o monoteísmo e o politeísmo constituem campos fundamentais da psique ocidental. Mas, é "preciso que sejamos mais astutos ao reconhecer o que surge do lado monoteísta da vida - consciência coletiva, crença, fé, e o que surge do lado mais reprimido, pagão, politeísta: as imagens arquetípicas" (López-Pedraza 1997, 39). E "é preciso considerar - diz o autor - que esse processo cultural ocidental, não leva em consideração nem histórias e nem geografias próprias".

Para argumentar, López-Pedraza $(1997,63)$ usa a própria experiência de homem caribenho, "produto histórico (...) do que se pode chamar o barroco latinoamericano." Uma mistura de cristianismo já em sua versão espanhola, que tenta um certo equilíbrio entre o monoteísmo trinitário e as antigas imagens arraigadas no Mediterrâneo, e mais um forte componente celta. Esse "sincretismo religioso", que produz sua própria ansiedade e seu próprio dinamismo, "tornouse ainda mais amplo quando da fusão com as numerosas religiões americanas autóctones, sem esquecer as religiões que os africanos traziam em suas almas". Nesse espaço, o eixo da dinâmica inclina-se para politeísmo, visto como inferior 
na relação com monoteísmo. “...eu sinto medo do monoteísmo e o vejo mais como um excesso ameaçador do que como algo que incitaria as imagens da alma, as imagens que nutrem o sentido da vida". E ademais, López-Pedraza $(1997,64)$ acrescenta que no "monoteísmo", embute-se "o monoteísmo norte-americano concebido a partir dessa mescla de racismo e religião, os brancos anglo-saxões e protestantes (WASPS), leitores da Bíblia...”, sem deixar de lembrar que do outro lado existe "a concepção monoteísta do ex-Estado soviético".

Se o afeto da angústia é constitutivo da existência humana; se é algo do qual não se pode fugir correndo; se a angústia é um momento de disposição especial do nosso ânimo que nos coloca em uma situação de mal-estar que não pode ser tributado a nada e, por isso, é o caminho que nos coloca face a face conosco mesmo, diante das nossas próprias condições individuais e singulares (Giacoia Júnior 2018), o artista portador do pathos agônico, num misto de ação e fracasso, tenta produzir na arte ou pela arte um resultado que a justifica [a angústia] e a transcende, uma vez que está enraizada na consciência do ato criativo como produto de um estado de crise. Essa dualidade que existe entre desejo de criar e instabilidade emocional, entre aspirações e conquistas, é a mesma experiência dos jovens poetas iconoclastas: Arthur Rimbaud, Baudelaire, Lautrèamont, e se remonta ao conceito essencial do Ser, a dicotomia que se estabelece entre o Bem e o Mal. A angústia não está longe da fantasia, disse Lacan $(2005,12)$. Ou, do mesmo autor, a angústia tem uma relação especial com o desejo do Outro (Lacan 2005, 14).

Para concluir, voltemos à epígrafe que se encontro no topo do artigo, um excerto da crítica que fez Julio Cortázar, em 1949, a Adán Buenosayres. Marechal toca, diz Cortázar, na "funda raiz do desassossego", toca "al fondo de la angustia occidental contemporânea”. O ápice da viagem do protagonista aconteceu na noite em frente à Igreja de São Bernardo, diante da imagem do Cristo de la Mano Rota. O Adán solitário em sua angústia, em sua sede de unidade, sente a mesma náusea que o melancólico Antoine Roquetin, personagem do livro de Sartre, $A$ Náusea, de 1938. "Deixei-me cair num banco... Gostaria tanto de me abandonar, de esquecer de mim (...). Mas não posso, sufoco: a existência penetra em mim por todos os lados ...” (Sartre 2016, 170).

\section{REFERÊNCIAS}

AGAMBEN, Giorgio. Estâncias. A palavra e o fantasma na cultura ocidental. Trad. Selvino José Assmann. Belo Horizonte: Ed. UFMG, 2007.

ALBÓS, Álvaro. Xul Solar. Pintor del misterio. Buenos Aires: Sudamericana, 2004.

ALMEIDA, Rogério Miranda de. Kierkegaard, Freud e o Conceito de Angústia. Podcast de Filosofia, FASBAM, 2019. Disponível em:

https://www.youtube.com/watch?v=MqqUBjwGyQs Acesso em: 07 jul. 2020.

ARENDT, Hannah. Entre passado e futuro. Trad. Mauro W. Barbosa de Almeida. São Paulo: Perspectiva, 1988.

ARRIGUCI JR., Davi. O cacto e as ruinas. A poesia entre outras artes. São Paulo; Ed. 34, 2000.

BENTO, Antônio. Ismael Nery. São Paulo: Gráficos Brunner Ltda., 1973.

CATÁLOGO. Xul Solar. Fundación Pan Klub. Museu Xul Solar. Buenos Aires, 1990.

CATÁLOGO. Ismael Nery - 50 anos depois. Curadoria: Aracy Amaral. São Paulo: Museu de Arte Contemporânea da Universidade de São Paulo. 1984. 
CEZARETTI, Maria Elisa Linardi de Oliveira. Poética Metafísica na Pintura da Modernidade Latino-Americana. Dissertação de Mestrado. SBD-FFLCH-USP, 1994.

CORDEIRO, André T. Ismael Nery: o olho no telescópio. Belém: Dissertação de Mestrado, 2003.

CORTÁZAR, Julio. Leopoldo Marechal: Adán Buenosayres. Revista Realidad, marzo/abril de 1949, p. 232-238. Disponível

em: https://www.oocities.org/juliocortazar_arg/marechalcri.htm. Acesso em: 07 ago. 2020.

CRISTIÁ, Cintia. Xul Solar. La música en su vida y obra. Buenos Aires: Gourmet Musical Ediciones, 2007.

FELINTO, Marilena. Opinião. Folha de São Paulo. 18/07/2020. Disponível em: https://www1.folha.uol.com.br/ilustrada/2020/07/livro-alienacao-e-liberdaderevela-enigmas-do-frantz-fanon-psiquiatra.shtml Acesso em: 23 jul. 2020.

FERNANDEZ, Senir Lourenço. Ismael Nery: a narrativa do essencial. In: AMARAL, Aracy (org.) Ismael Nery 50 anos depois. São Paulo: AC-USP, 1984. p. 148-166.

FLORES, Maria B. R. Tecnologia e estética do racismo. Chapecó/SC: Argos, 2007.

FLORES, Maria B. R. Xul Solar e Ismael Nery entre outros misticos modernos. Sobre o revival espiritual. Campinas/SP: Mercado de Letras, 2017.

FLORES, Maria B. R. Imagem e memória. As musas inquientantes. In: PATRIOTA, R., RAMOS, A. F., PESAVENTO, S. J. (Orgs.). Imagens na História - Objetos de História Cultural. São Paulo: HUCITEC, 2008, p.185-225.

FREUD, Sigmund. O infamiliar (Das Unheimliche). Trad. Ernani Chaves e Pedro H. Tavares. Belo Horizonte: Autêntica, 2019.

GIACOIA JÚNIOR, Oswaldo. Podcast. Kierkegaard: angústia e esperança. 10/04/2018. Disponível em: https://www.youtube.com/watch?v=VjGG14EREAo Acesso em: 20 jul.2020.

GIROLA, Roberto. Podcast. A angústia (Freud e a Filosofia). Junho de 2000. Disponível em: https://www.robertogirola.com.br/index.php/item/720-angustia-freud Acesso em: 06 jul.2020.

GREENBLATT, Stephen. Ascensão e queda de Adão e Eva. Trad. Donaldson M. Garschagen. São Paulo: Companhia das Letras, 2018.

GLUSBERG, Jorge. Xul Solar Y la angustia como liberación de lo finito. In: CATÁLOGO. Xul Solar en el Museo Nacional de Bellas Artes. Buenos Aires: MNBA, 1998.

GLUSBERG, Jorge. El arte paralelo de Paul Klee y Xul Solar. CATÁLOGO. Paul Klee invita a Xul Solar en el Museo Nacional de Bellas Artes. Buenos Aires: MNBA, 1990 , p. 13.

GÓMEZ, Pedro P., MIGNOLO, Walter. Estéticas decoloniais. Bogotá: Libros Electrónicos, 2012.

GRADOWCZYK, Mario (1994). Alejandro Xul Solar. Buenos Aires: Ed. Alba, Fundación Bunge y Born.

IVO, Ledo. Prefácio. RIMBAUD, Artur. Uma temporada no Inferno \& Iluminações. Trad. Lêdo Ivo. Rio de Janeiro: Francisco Alves, 2004.

KIERKEGAARD, Soren. O conceito de angústia. Trad. Torrieri Guimarães. São Paulo: Hemus, 1968.

LACAN, Jacques. Angústia. Seminário 10. Trad. Vera Ribeiro. Rio de Janeiro: Zahar, 2005.

LÓPEZ-PEDRAZA, Rafael. Ansiedade Cultural. Trad. Roberto Cirani. São Paulo: Paulus, 1997.

MARECHAL, Leopoldo. Adán Buenosayres. Barcelona: EDHASA, 1981. 
MARECHAL, Leopoldo. Adán Buenosayres. La Baldrich - Espacio de Pensamiento Nacional Disponível em: http://www.labaldrich.com.ar/wpcontent/uploads/2013/03/Ad\%C3\%A1n-Buenosayres-Leopoldo-Marechal.pdf Acesso em: 01 jul. 2020.

MATURO, Graciela. Marechal, el caminho de la beleza. Buenos Aires: Biblos, 1999.

MENDES, Murilo. Recordaçôes de Ismael Nery. São Paulo: EDUSP; Editora Giordano, 1996.

NELSON, Daniel E. Los san signos de Xul Solar: El libro de las mutaciones. In: CATÁLOGO. Xul Solar: Visiones y revelaciones. Buenos Aires; São Paulo: MALBA; Pinacoteca, 2005, p. 49-59.

PASCAL, Blaise. Pensamentos. Trad. Sérgio Milliet. São Paulo: Abril Cultural, 1973.

READ, Herbert. Escultura Moderna. Trad. Ana Aguiar Cotrim. São Paulo: Martins Fontes, 2003.

ROCCO-CUZZI, Renata. Las epopeyas de Leopoldo Marechal. JITRIK, Noé. História critica de la literatura argentina. Vol. 9. Buenos Aires: Emecé Editores, 2004.

ROUDINESCO, Elisabeth. Dicionário amoroso da psicanálise. Trad. André Telles. Rio de Janeiro: Zahar, 2019.

SARLO, Beatriz. El caso Xul Solar. Invención fantástica y nacionalidad cultural. In. CATÁLOGO. Xul Solar. Madrid, Museu Nacional Centro de Arte Reina Sofía, 2002, p. 45-55.

SANT'ANA, Affonso Romano de. Ismael Nery: a circularidade do um, do dois e do três. In: CATÁLOGO. Ismael Nery - 100 anos: a poética de um mito. Curadoria: Denise Mattar. São Paulo: Fundação Armando Álvares Penteado, 2000, p. 59-62.

SARTRE, Jean-Paul. A Náusea. Trad. Rita Braga. Rio de Janeiro: Nova Fronteira, 2016.

SHEERWOOD, Gregory. Gente de mi ciudad: Xul Solar, campeón mundial de panajedrez y el inquieto creador de la 'panlingua'. In: ARTUNDO, Patrícia M. (Org.). Xul Solar. Buenos Aires: Corregidor, 2005, p. 75-80.

XUL SOLAR, Alejandro: Entrevistas, articulos y textos inéditos, Introducción, investigación, selección y organización de Patricia M. Artundo, Buenos Aires, Corregidor, 2005.

\author{
A ANGÚSTIA DE ADÃO NA AMÉRICA \\ ARTIGO RECEBIDO EM 01/09/2020 • ACEITO EM 26/11/2020 \\ DOI | https://doi.org/10.5216/rth.vi2.65405 \\ REVISTA DE TEORIA DA HISTÓRIA | ISSN 2175-5892
}

\title{
c)
}

ESTE E UM ARTIGO DE ACESSO LIVRE DISTRIBUIDO NOS TERMOS DA LICENCCA CREATIVE COMMONS ATTRIBUTION, QUE PERMITE USO IRRESTRITO, DISTRIBUIÇÃO E REPRODUÇÃO EM QUALQUER MEIO, DESDE QUE O TRABALHO ORIGINAL SEJA CITADO DE MODO APROPRIADO 